\title{
As Comissões Nacionais Especializadas
}

Uma das grandes criações da FEBRASGO foram as Comissões Nacionais Especializadas. Várias são suas funções. A primeira é estudar profundamente um tema específico, tomando consciência do que de mais atual existe. A segunda é divulgar esse conhecimento para que todos se beneficiem de seu trabalho e o possam aplicar para o bem coletivo. Femina, RBGO e o Jornal da FEBRASGO, são os instrumentos que devem ser utilizados, tanto para os aspectos científicos como para anunciar eventos e locais onde seja possível a reciclagem médica. A terceira é participar ativamente em eventos científicos, quando solicitado, junto e de comum acordo com as Federadas, para que os sócios tenham a oportunidade de se atualizar e dirimir suas dúvidas. A quarta é de dar respaldo técnico à FEBRASGO, quando esta for instada a opinar sobre determinado assunto perante os órgãos responsáveis pela promoção da saúde em nosso país, no Mercosul ou na Federação Internacional de Ginecologia e Obstetrícia. Para que isso se tornasse realidade, a Diretoria da FEBRASGO ouviu as Federadas e garimpou nomes que, comprovadamente, pesquisam, praticam e publicam nas áreas em questão e, juntamente, com os Presidentes das Comissões, completou a formação das mesmas. Um vice-presidente e um secretário darão o respaldo administrativo necessário.

A Diretoria da FEBRASGO, assim, considera que concluiu a primeira parte do estabelecido para seu mandato. Com todos os setores funcionando, agora é hora de trabalhar, esperando que as Comissões tenham um crescimento homogêneo e contínuo, para benefício do universo de ginecologistas e obstetras que querem, precisam e acreditam que cada Comissão vá cumprir sua função.

\section{A Diretoria}

